\title{
Using Geographic Information System and Analytical Hierarchy Process in Landslide Hazard Zonation
}

\author{
Bharat Prashad Bhatt, Keshab Datt Awasthi, Binod Prasad Heyojoo, Thakur Silwal, Gandhiv Kafle* \\ Department of Forest, District Forest Office, Nuwakot, Nepal \\ *Corresponding author: gkafle@ scientist.com
}

Received December 18, 2012; Revised March 27, 2013; Accepted April 15, 2013

\begin{abstract}
Nepal frequently suffers from various types of water induced disasters like soil erosion, landslide, debris flow, flood etc. To mitigate the problem related to Landslides \& Debris flow, Landslide Hazard zonation is important to quick and safe mitigation measures and make strategic planning for the future by identifying the most vulnerable areas and channelizing most of the protective measures and techniques to a more focused area. This study was carried out in Rupa watershed area of kaski district with the main objective of identifying the landslide triggering factors and making the landslide hazard zonation map of the study area. Analytical Hierarchy Process (AHP) and Geographic Information System (GIS) were entirely employed for the preparation of Landslide Hazard Zonation mapping. The main factors responsible for the occurrence of landslide was found to be slope, aspect, landcover, presence of roads and presence of river and streams. Among these factors, the presence of road factors had the prominent effect on landslide occurrence. Altogether 13 landslide events were recorded in the study area and among them most of the landslide events were seen in Rupakot Village Development Committee (VDC). The final landslide susceptibility map of the study area can help the development planners to know more about the area and disseminate their development project in accordance with the need base approach. Proper development plan, proper system of keeping the records of landslide events, broadcasting high susceptible zones for landslides, implementing appropriate conservation technology, giving instructions to the locals can help to minimize these kind of natural disasters.
\end{abstract}

Keywords: landslide, hazard, AHP, GIS

\section{Introduction}

There are now so many methods and techniques for analysing the landslide hazard zonation. The main goal of the analysis of the landslide hazard zonation is to reduce the impact of the land sliding by determining and categorizing the most vulnerable areas and which are at great risk. The analytic hierarchy process (AHP) was developed at the Wharton School of Business by Thomas Saaty in the late 1970s. It is a decision making tool for handling with complex, unstructured, and multi-criteria decisions. It provides a flexible and easily understandable way of analyzing complicated problems, and allows modifying ideas related with landslide and solving problems by making approximate assumptions. It also allows incorporating both objective and subjective considerations in the decision process [25]. Recently, new decision-support tools, including AHP and weighted linear combination models, have been developed for GIS-based heuristic approaches. Although these methods are considered to be semi-quantitative [3], they can be effectively used for medium-scale assessments of landslide susceptibility [10,28].

In mountainous countries, vulnerability, hazard, and risk are everywhere and for vulnerability assessment the AHP is highly applicable even in the case of Nepal. Nepal is such a country, characterized as it is by a rugged topography with high relief, complex geological features, concentrated rainfall, and a dense population. A larger part of the country is vulnerable to natural hazards such as earthquakes, landslides, debris flows, floods, drought, and other associated phenomena. A variety of physiographic, geological, ecological, and meteorological factors contribute to these hazards; whereas demographic factors such as rapid population growth, improper land use, economic underdevelopment, and the resulting dire poverty and widespread ignorance of the possibilities and means of mitigation exacerbate them [21]. Mountain systems are characterized by substantial differences in environmental characteristics due to rapid and sharp changes in altitude. This leads to specific dynamics of hydrological processes with important positive and negative consequences (high water yield due to high amount of precipitation, disastrous floods with soil losses resulting in high sediments loads in rivers). Despite these fragile circumstances, significant number of poor and vulnerable people often resides in such environments, adopting typical socio-economic activities [1].

Landslide becomes a problem when they interfere with human lives, activities and properties. The frequency and the magnitude of slope failures can increase due to human activities such as deforestation, cultivation in marginal lands or urban expansion. This event may disrupt the normal pattern of the human life and if higher magnitude 
of event occurs, community needs external support to recover. These phenomena are common in Nepalese mountains [19]. Mitigation of landslide disasters can be successful only when detailed knowledge is obtained about the expected frequency, character and magnitude of landslide in the area. The zonation of landslide hazard may be the basis for any landslide disaster mitigation work and can supply planner and decision-makers with adequate and understandable information.. Landslide hazard analysis is a complex task. It requires large number of input parameters and techniques for analysis. The process involves both cost and time [23].

\section{Study Area}

Rupa watershed area (Figure 1), which is situated in Kaski district of Nepal at an elevation of $600 \mathrm{~m}$ asl. Rupa Lake is the third biggest lake of Pokhara valley. It is elongated north to south and the main inflow of water is from Talbesi stream, whereas Dhovan Khola is the feeder stream with its outlet Tal Khola at Sistani ghat, joining the Seti Gandaki. The lake area is 115 ha and its watershed boundary which I have delineated is $22.75 \mathrm{sqkm}$. The watershed area in the eastern portion is covered with mixed forest of Chilaune (Schima wallichii) and Katus (Castanopsis indica) and hill slope to the west is covered partially with vegetation and cultivated land. The northern slopes are privately owned terraced land for agriculture crops, and some floating aquatic vegetation, grasses and rice fields are found in the lake shoreline.

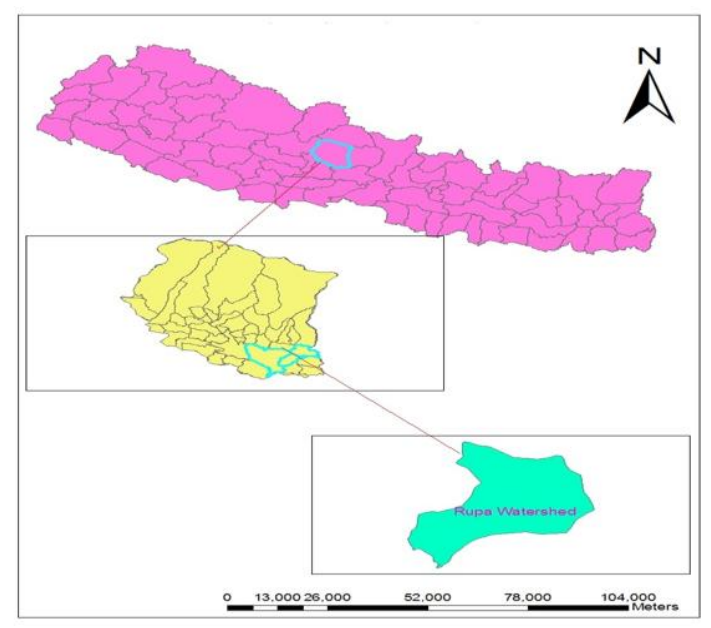

Figure 1. Map of the Study Area

\section{Methodology}

In this study, ArcGIS 9.3 version, DNR Garmin 5.04.0001version and GPS (Etrex, Garmin) were used for the entire analysis. Topographic map of Kaski District (having the layers like, land cover map, slope map, aspect map, road map, river map etc), sheet no. 2884-13a, 13b obtained from Survey Department, Ministry of Land Reform and Management, Nepal, 1984 and Geological map of parts of Kaski and Tanahun Districts (1996), sheet no. 71D/4, obtained from Department of Mines and Geology were also used for the analysis. Desk study was accompanied by having with different literatures. On the basis of these literatures, the main factors responsible in Landslide occurrence called triggering factors, were studied that included rainfall, earthquake, rock type, construction works, slope, aspect, presence of river and streams, geological information like the presence of fault or thrust. A preliminary survey was conducted to locate existing active landslides in the study area with the help of local people as well as the district soil conservation office (DISCO) staff of the Kaski district.

After locating the existing landslides, boundary survey of the landslides along with a simple key informant interview and morphometric study of the landslides was carried out. Each landslide was visited and the boundary was surveyed using GPS. Also morphometric data of each of them was collected using the field data sheet. The morphometric data of the landslides includes the location of the landslides, lithological structure, vegetation cover, type of land use around the landslide, slope, road construction, river, and water ways, altitude and aspect. The data collected from the boundary survey was downloaded into DNR Garmin software and exported to ArcGIS 9.3 to prepare digital landslide distribution map so that the prepared distribution map could be overlaid with the other maps to determine the landslide triggering factors. For the investigation of the triggering factors which were actually responsible of landslide occurrence in the study area, the different triggering factor maps were prepared using the GIS Software. The different factor maps include lithology (rock type) factor map, slope factor map, land use factor map, motorable road factor map, rivers and streams factor map and aspect factor map. Again, each map is classified into several classes. For earthquake factor map, as the detailed earthquake hazard map of the study area could not be found, despite earthquake being one of the prominent triggering factors and could not be considered in this study. Similarly, for soil depth, soil texture and subsurface water flow factor map, as the detailed soil map could not be found during the study, they were left out in this study. Dam construction and mining factor maps were not prepared because of their absence in the study area. No dams and mines were noticed during the field study.

Relational analysis was carried out for the investigation of landslide triggering factors. For the analysis, firstly, the landslide area of a particular class of each of triggering factor maps was determined by using the Zonal Histogram Function in the ArcGIS Spatial Analyst. After that percentage of area of the factor class covered by landslide area for each factor class of the different factors was computed by simple mathematical calculation. Thus, the percentages of area covered by the landslide in each class of the different factors were computed and a subjective relational analysis between the percentages of area covered by landslide and the factor classes were carried out. Actual triggering factors were thus calculated by some sort of relation between the factor classes and the percentages of area covered by landslide and if otherwise that factor was left out. The triggering factors thus calculated were then used for the further analysis. Satty (1980) [20], developed the AHP to standardize the multifactor decision-making process. AHP provides a hierarchical structure by reducing multiple variable decisions into a series of couple/pair comparisons and develops subjective priorities based upon the user's 
judgment. While applying AHP, factors are compared with each other to determine the relative preference of each factor in accomplishing the overall goal. Numerical values are assigned to each pair of the factors using the guidelines established in Fundamental Satty's Scale (Table 1). The AHP in detail involves the accomplishment of the following steps in a sequence.

Table 1. Satty's Scale For Comparison (Satty 1980)

\begin{tabular}{|c|c|c|}
\hline Scales & Degree of Preference & Explanation \\
\hline 1 & Equally & $\begin{array}{c}\text { Two activities contribute } \\
\text { equally }\end{array}$ \\
\hline 5 & Strongly & $\begin{array}{c}\text { Experience and judgment } \\
\text { slightly to moderately favor } \\
\text { one activity to another }\end{array}$ \\
\hline 7 & Very strongly & $\begin{array}{c}\text { Experience and judgment } \\
\text { Strongly or essencially favour } \\
\text { one activity over another }\end{array}$ \\
\hline 9 & Extremely & $\begin{array}{c}\text { One activity is strongly } \\
\text { favored over another and its } \\
\text { dominance is showed in } \\
\text { practice }\end{array}$ \\
\hline $2,4,6,8$ & Intermediate values & $\begin{array}{c}\text { The evidence of favoring one } \\
\text { activity over another is of the } \\
\text { highest degree possible of an } \\
\text { affirmation }\end{array}$ \\
\hline Reciprocals & Opposites & $\begin{array}{c}\text { Used to represent } \\
\text { preferences in weights } 1,3,5,7 \\
\text { and 9 }\end{array}$ \\
\hline
\end{tabular}

\subsection{Couple Comparison of the Triggering Factors and Their Prioritization Based on Their Derived Weight Values}

The couple comparison method was used to determine the preference of the triggering factors. For couple comparison, the factors identified as the actual triggering factors in the above step were arranged in the form of the matrix as shown in Table 2 and the factors were subjectively compared with each other as a couple and their preference were expressed in the numeric values in the adjacent cells i.e. the factors preferences were quantified. Once the preferences of the factors have been determined using the couple comparison method, the alternative weight of the couple comparison matrix was calculated using arithmetic mean method. In this method, at first, the values of each columns of couple comparison matrix are summed up. Then the values in the each cell of the matrix is divided by the summed value of the same factor column, and at last, the factor mean values were derived in each row as mean of the values in each row. These mean values of each row were the weight values (let us say ' $y$ ') of each factor. The example can be shown as:

Table 2. Matrix Showing The Couple Comparison Of The Factors

\begin{tabular}{|c|c|c|c|c|c|}
\hline & $\begin{array}{c}\text { Presence } \\
\text { of road }\end{array}$ & slope & Aspect & $\begin{array}{c}\text { Presence of } \\
\text { river and } \\
\text { stream }\end{array}$ & $\begin{array}{c}\text { Land } \\
\text { cover }\end{array}$ \\
\hline $\begin{array}{c}\text { Presence of } \\
\text { road }\end{array}$ & $\mathrm{a}$ & $\mathrm{b}$ & $\mathrm{c}$ & $\mathrm{d}$ & $\mathrm{e}$ \\
\hline Slope & $1 / \mathrm{b}$ & $\mathrm{a}$ & $\mathrm{f}$ & $\mathrm{g}$ & $\mathrm{h}$ \\
\hline Aspect & $1 / \mathrm{c}$ & $1 / \mathrm{f}$ & $\mathrm{a}$ & $\mathrm{i}$ & $\mathrm{d}$ \\
\hline $\begin{array}{c}\text { Presence of } \\
\text { river and } \\
\text { stream }\end{array}$ & $\ldots$ & $\ldots$ & $\ldots$ & $\mathrm{a}$ & $\mathrm{c}$ \\
\hline Land cover & $\ldots$ & $\ldots$ & $\ldots$ & $\ldots$ & $\mathrm{a}$ \\
\hline Sum & $\ldots$ & $\ldots$ & $\ldots$ & $\ldots$ & $\ldots$ \\
\hline
\end{tabular}

In the matrix where the values of variables a..... z varies from 1 to 9 and the diagonal matrix always contains the value of 1 (Table 2), the pair wise comparison between the factors on the vertical column and the factors on the horizontal row was carried out and the preferences of the factors were recorded in their corresponding intersecting cells. Here in the Table 2, in case of the top-left cell, when the factor in the vertical column i.e. presence of road type was compared with the factor in the horizontal row i.e. presence of road type, the two factors being same hence equally preferred so the cell was assigned the numerical value of 1 , meaning that the two factors in the vertical column i.e. presence of road type and horizontal row i.e. presence of road type are equally preferred. Similarly, in case of the top- right cell, when the factor in the vertical column i.e. presence of road was compared with the factor in the horizontal row i.e. land cover, the presence of road Factor was judged to be extremely preferred over the land cover Factor, thus cell was assigned the numerical value of 9 meaning that the factor in the vertical column i.e. presence of road was extremely preferred in comparison to the factor in the horizontal row i.e. land cover. In the similar fashion all the cells, diagonally in the upper half of the matrix, were filled and rest half was filled by their reciprocals. Then, the numerical values assigned in the cells were summed up column-wise and were recorded in the last row as sum.

\subsection{Giving Weight Values to Each Class of Factors}

The weight values were given to each class of factors on the basis of the percentages of area covered by the landslide area in each of them. All the classes of the different factors were given values from 0-100 (let us say ' $\mathrm{m}$ ' values). For this, firstly, the percentages of area covered by the landslide area in each class of different factors were determined. Then the class of each factor having the maximum percentage of area covered by the landslide area was given the maximum value i.e. 100 and the class having the minimum percentage of area covered by the landslide area was given the minimum value i.e. 0 and then other classes with the percentage of area covered by the landslide area in between them were given intermediate values on proportional basis.

\subsection{Zonation of the Study Area}

After giving weight values to all classes of the different triggering factors i.e. the weight values of the factor classes $(\mathrm{m})$ and the weight values to the factors i.e. the weight values of the factors $(\mathrm{Y})$, the cumulative weight value (i.e. Susceptibility Coefficient) for each grid was calculated using the LHZ model developed by Esmali (2003):

$$
\mathrm{M}=\mathrm{Y} 1 * \mathrm{X} 1+\mathrm{Y} 2 * \mathrm{X} 2+\ldots
$$

Where,

$\mathrm{M}=$ cumulative weight value = Susceptibility Coefficient

$\mathrm{X} 1, \mathrm{X} 2, \ldots=$ ' $\mathrm{m}$ ' values related to the triggering factors $\mathrm{x} 1, \mathrm{x} 2, \ldots$ and

$\mathrm{Y} 1, \mathrm{Y} 2, \ldots=$ the weight values related to $\mathrm{x} 1, \mathrm{x} 2, \ldots$ factors 
Thus, calculated ' $M$ ' values ranges from 0-100. Lower the value of ' $M$ ', lower is the susceptibility and higher the value, higher is susceptibility to landslide occurrence. Hence, for zonation of the study area, it was classified into 5 relative hazard classes i.e. very low, low, medium, high, and very high by unequal interval classification method. Finally, with the completion of all the above mentioned steps the Landslide Hazard Zonation (LHZ) Map of the study area was prepared using AHP method.

Once the LHZ Map was prepared, for better understanding and interpretation of the LHZ Map, the map was further analyzed using the Zonal Histogram Function in the ArcView Spatial Analyst and the hazard susceptibility condition of the different classes of the different Triggering Factors were computed.

\subsection{Evaluation of Applicability of AHP for Landslide Hazard Zonation}

The Zonal Histogram Function in the ArcGIS Spatial Analyst was used again to determine the percentages of area in each hazard class covered by the landslide area. Finally, these percentages of area covered by the landslide area were taken as the basis of the evaluation.

\section{Data}

\subsection{Landslide Inventory}

From the field survey, a total of 13 landslides were investigated in different location of the study area. The overall landslide density in the study area was found to be $0.571 / \mathrm{km}^{2}$ (landslide density $=$ total number of landslide located within the study area/ total area of the watershed boundary). The overall study area was $22.75 \mathrm{~km}^{2}$ and the area covered by landslides is $4467 \mathrm{~m}^{2}$. The final landslide distribution map prepared by combining topographic map of the study area and the GPS points collected during the field study is shown in the Figure 2. It can be seen from the Figure 2 that most of the landslides were found in the Rupakot VDC and only one was found in the Hanspur VDC. Some landslides were also found in Lekhnath municipality as well. The largest of the landslides was found in Rupakot VDC, the area of which is $1452 \mathrm{~m}^{2}$.

\subsection{Factors Triggering on Landslide Occurrence}

The factors actually responsible for the landslide occurrence were calculated by the relational analysis as slope, aspect, landcover, distance from river and stream and distance from road. Despite being the important factors, the rainfall and geology factors were excluded in this study. For rainfall factor, the average daily rainfall of the whole Kaski district is more of less same and there were no network of weather stations installed in the study area so triggering effect of the rainfall factor was assumed to be uniform throughout the study area. Owing to this fact, the rainfall factor was not considered during the landslide hazard zonation factor computation. For geology factor, the study area has only the geological factors like alluvial deposits and kuncha formation but not the faults and thrusts. While doing the relational analysis between the factors, no correlation was found. Hence, the geology factor was also not considered for the further analysis in spite of being one of the prominent factors triggering the landslide. The area of each of the factor is shown in Table 3.

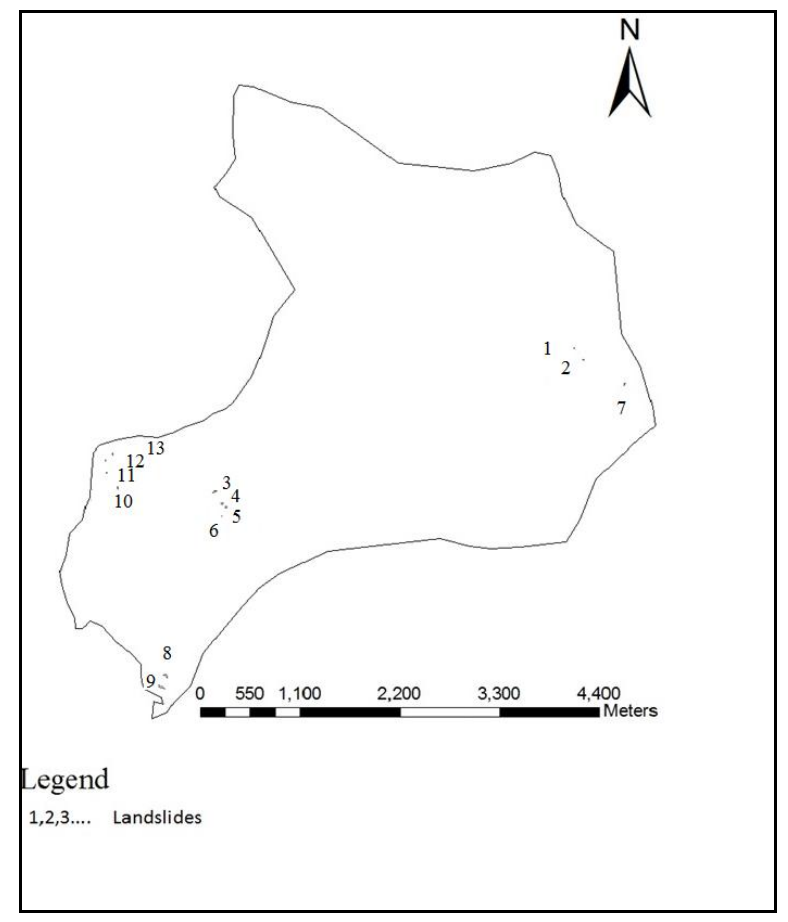

Figure 2. Landslide Distribution Map

Table 3. Area of Each Factor Class Covered by the Landslide in Percentage

\begin{tabular}{|c|c|c|c|}
\hline S.N. & Factor Class & Area in ha & $\begin{array}{l}\% \text { of Area of } \\
\text { Each } \\
\text { Class Covered } \\
\text { by LS }\end{array}$ \\
\hline \multicolumn{4}{|c|}{ Slope Factor } \\
\hline 1 & $<5$ & 297.25 & 0.010 \\
\hline 2 & $5-30$ & 1944.00 & 0.021 \\
\hline 3 & $>30$ & 33.00 & 0.000 \\
\hline \multicolumn{4}{|c|}{ Aspect Factor } \\
\hline 1 & $\mathrm{~N}$ & 871.50 & 0.009 \\
\hline 2 & $\mathrm{E}$ & 198.75 & 0.017 \\
\hline 3 & $\mathrm{~S}$ & 923.50 & 0.006 \\
\hline 4 & $\mathrm{~W}$ & 280.75 & 0.093 \\
\hline \multicolumn{4}{|c|}{ Land Cover Factor } \\
\hline 1 & Cultivation & 1029.66 & 0.022 \\
\hline 2 & Forest & 1087.84 & 0.019 \\
\hline 3 & Water body & 113.10 & 0.000 \\
\hline 4 & Others & 36.19 & 0.000 \\
\hline \multicolumn{4}{|c|}{ Presence of Road Factor } \\
\hline 1 & $0-50$ & 663.45 & 0.026 \\
\hline 2 & $50-100$ & 476.38 & 0.009 \\
\hline 3 & $100-150$ & 332.57 & 0.005 \\
\hline 4 & $150-200$ & 249.14 & 0.003 \\
\hline 5 & $200-250$ & 179.36 & 0.000 \\
\hline 6 & $250-300$ & 130.49 & 0.000 \\
\hline \multicolumn{4}{|c|}{ Presence of River and Stream Factor } \\
\hline 1 & $0-50$ & 841.02 & 0.019 \\
\hline 2 & $50-100$ & 634.59 & 0.013 \\
\hline 3 & $100-150$ & 388.58 & 0.009 \\
\hline 4 & $150-200$ & 218.30 & 0.003 \\
\hline 5 & $200-250$ & 104.12 & 0.000 \\
\hline 6 & $250-300$ & 45.31 & 0.000 \\
\hline
\end{tabular}

\subsubsection{Slope Factor}

The slope class, 5-300 covered the higher percentage of area covered by landslide compared to the slope class $<50$ (Table 3), Reasonably, this might be due to fact that most 
of the study area (almost 85\%) lies within this slope category where there is the dominant of weathered rock which makes the area more susceptible to land sliding.

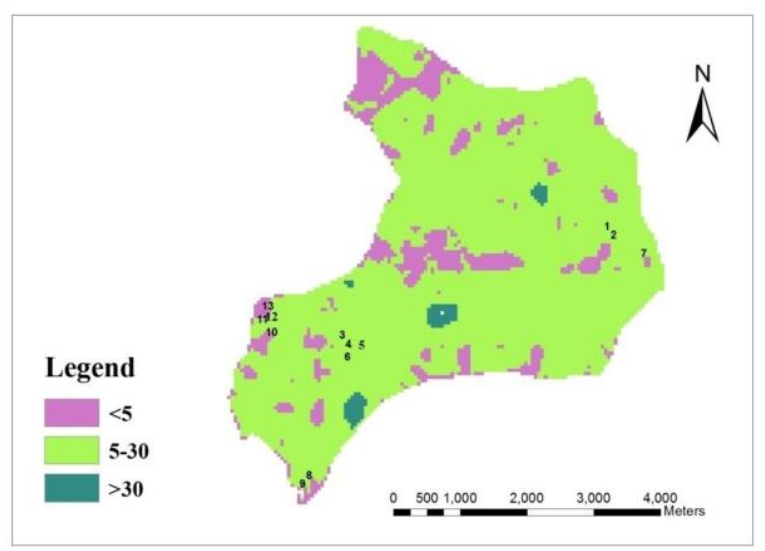

Figure 3. Slope Map of the Study Area

\subsubsection{Aspect Factor}

West facing slopes (Figure 4) covered the higher percentage of landslide area while south facing slopes covered the lowest percentage of landslide area. The cumulative effect of land cover made the west facing slopes susceptible for landslide. Again due to more settlements and presence of motorable road in the west facing slopes, there were more landslides in the western slopes.

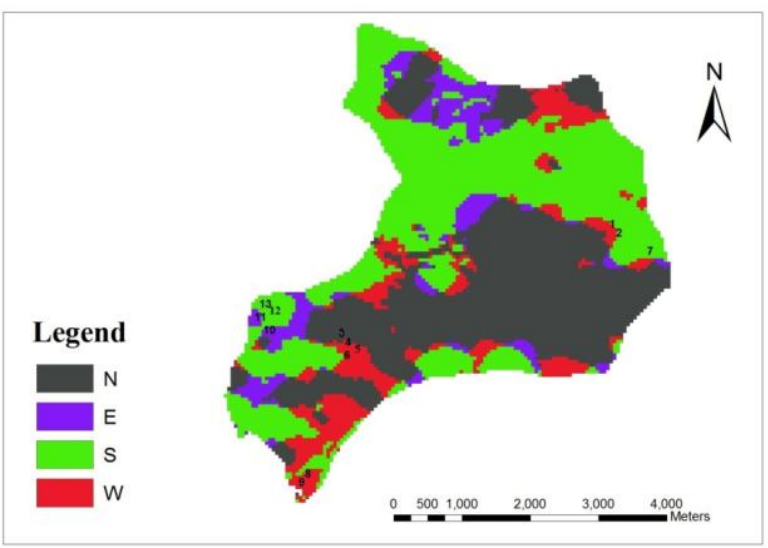

Figure 4. Aspect Map of the Study Area

\subsubsection{Presence of Road Factor}

The distance from road classes (Figure 5) closer to the road covered the higher percentage of landslide area while the classes far from the road had lowest percentage of landslide i.e. the relation is in inversely proportional to the distance from the road. This might be because the presence of road triggers landslide mainly due to the undercutting of the slope and when the area is far from the road, the tremors caused by the vehicle goes on decreasing.

\subsubsection{River/Stream Factor}

The class closer to river/stream (Figure 6) covered the higher percentage of landslide. Water in the streams/river that increases in the rainy season cuts deep in the side of the river/stream banks and makes it hazardous. Also if the stream bed is full, it takes another course and undercuts base of the slope. The water that is driven from the stream/river for the irrigation if taken in an improper way can further deteriorate the condition and makes the land more prone to landslides.

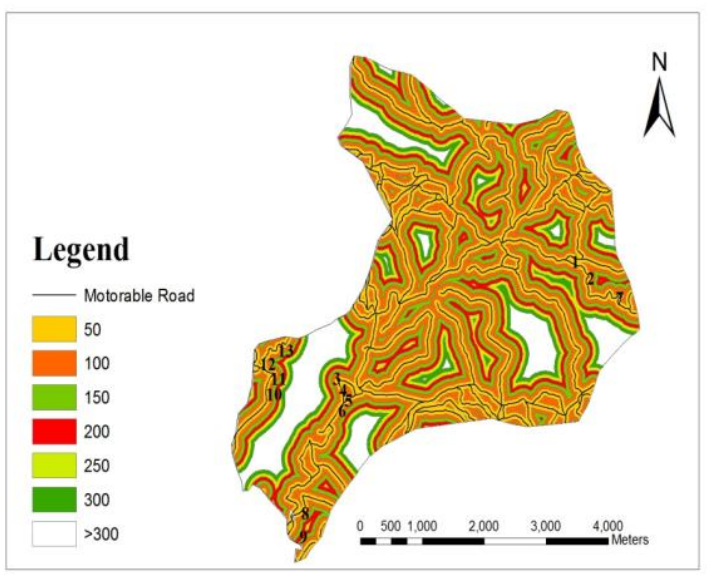

Figure 5. Distance from Road Map of the Study Area

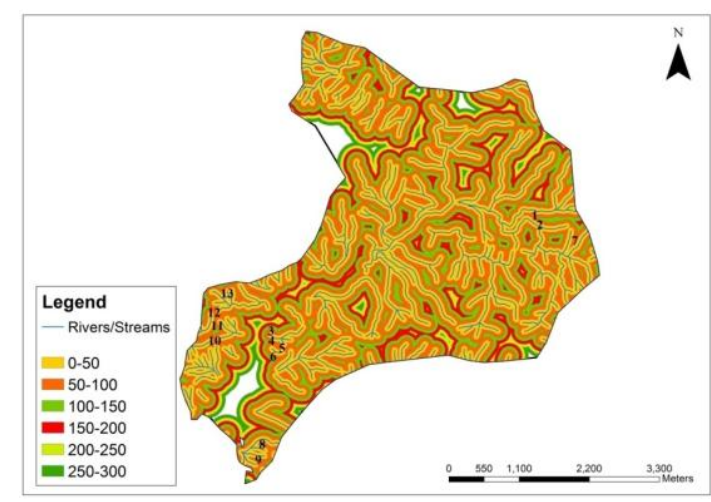

Figure 6. River/Stream Factor Map of the Study Area

\subsubsection{Landcover Factor}

Land cover indicates indirectly that slopes are stabilized, barren, and sparsely vegetated areas exhibit faster erosion and greater instabilities than forests $[24,17,8,6]$. In land cover category (Figure 7), cultivated land covered the higher percentage of landslide event in the study area followed by forest lands. Because vegetation plays important role for curbing the landslide, forest land was found comparatively less susceptible to erosion hazard. Clearing forest sites for cultivation and an improper way of farming technique plays important roles in triggering landslides. The category "others" in Figure 7 denotes sand, gravel and boulders.

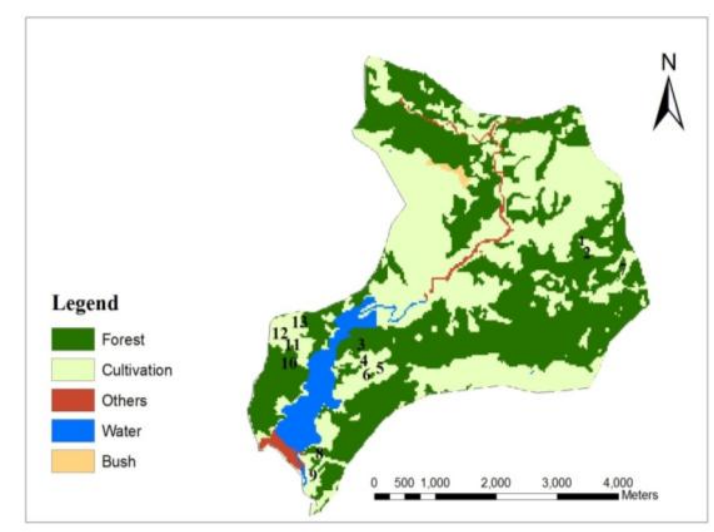

Figure 7. Landcover Factor Map of the Study Area 


\subsubsection{Preferences and Weight Values of the Triggering Factors}

The preferences and weight values of the triggering factors determined by the couple comparison method are shown in Table 4:

Table 4. Matrix Showing The Couple Comparison Of The Factors

\begin{tabular}{|c|c|c|c|c|c|}
\hline & $\begin{array}{c}\text { Presence } \\
\text { of Road }\end{array}$ & Slope & Aspect & $\begin{array}{c}\text { Presence of } \\
\text { River and } \\
\text { Stream }\end{array}$ & $\begin{array}{c}\text { Land } \\
\text { Cover }\end{array}$ \\
\hline $\begin{array}{c}\text { Presence of } \\
\text { Road }\end{array}$ & 1 & 5 & 5 & 7 & 9 \\
\hline Slope & $1 / 5$ & 1 & 4 & 5 & 7 \\
\hline Aspect & $1 / 5$ & $1 / 4$ & 1 & 4 & 5 \\
\hline $\begin{array}{c}\text { Presence of } \\
\text { River and } \\
\text { Stream }\end{array}$ & $1 / 7$ & $1 / 5$ & $1 / 4$ & 1 & 4 \\
\hline Land Cover & $1 / 9$ & $1 / 7$ & $1 / 5$ & $1 / 4$ & 1 \\
\hline Sum & 1.65 & 6.59 & 10.45 & 17.25 & 26 \\
\hline
\end{tabular}

For the computation of the mean in Table 5, the values in each cell in Table 4, were firstly divided by their corresponding column sum and then results were recorded in the corresponding cells of Table 6. Finally, the mean values for each factor were calculated row-wise. These row wise means represent the factor weight value. Therefore, the priority of each factors based on the earned weight values was as shown in the last column of Table 5.

Table 5. Arithmetic Mean Method for Calculating the Factor Weight Values

\begin{tabular}{|c|c|c|c|c|c|c|}
\hline & $\begin{array}{c}\text { Presence } \\
\text { of Road }\end{array}$ & Slope & Aspect & $\begin{array}{c}\text { Presence } \\
\text { of River } \\
\text { and } \\
\text { Stream }\end{array}$ & $\begin{array}{c}\text { Land } \\
\text { Cover }\end{array}$ & $\begin{array}{c}\text { Mean } \\
\text { (y) }\end{array}$ \\
\hline $\begin{array}{c}\text { Presence } \\
\text { of Road }\end{array}$ & 0.606 & 0.758 & 0.478 & 0.405 & 0.346 & 0.5186 \\
\hline Slope & 0.121 & 0.151 & 0.382 & 0.289 & 0.269 & 0.2424 \\
\hline Aspect & 0.121 & 0.037 & 0.095 & 0.231 & 0.192 & 0.1352 \\
\hline $\begin{array}{c}\text { Presence } \\
\text { of River } \\
\text { and }\end{array}$ & 0.086 & 0.030 & 0.023 & 0.057 & 0.153 & 0.0698 \\
Stream & 0.067 & 0.021 & 0.019 & 0.014 & 0.038 & 0.0318 \\
\hline $\begin{array}{c}\text { Land } \\
\text { Cover }\end{array}$ & & & & & & \\
\hline
\end{tabular}

\subsubsection{Weight Values of the Factor Classes}

The weight values of the different factor classes were determined based on the percentages of area of each class of different factors covered by the landslide area. In presence of road factor, the higher percentage of area of factor class 150-200 was covered by the landslide area thus it was given highest factor class weight value i.e. 100, which when multiplied with the factor weight gave the actual weight value of 51.86 as shown in Table 7, whereas the lowest percentage of area of factor classes 200-250 and 250-300 was covered by the landslide area thus it was given the lowest factor class weight value i.e. 0, which on multiplication with the factor weight yielded the actual weight value of 0 . Similarly, the weight values of the other factor classes were also determined and the details are presented in Table 6.
Table 6. Details of the Determination of the Weight Values of the 5 Factors Classes

\begin{tabular}{|c|c|c|c|c|c|c|}
\hline $\begin{array}{l}\mathrm{S} \\
\mathrm{N}\end{array}$ & $\begin{array}{l}\text { Factor } \\
\text { Class }\end{array}$ & $\begin{array}{c}\text { Area of } \\
\text { Class } \\
\text { (ha) }\end{array}$ & $\begin{array}{l}\% \text { Area } \\
\text { Covere } \\
\text { d by LS }\end{array}$ & $\begin{array}{c}\text { Weight } \\
\text { by } \\
\% \text { of } \\
\text { LS } \\
\text { Covere } \\
\text { d } \\
\text { Area }\end{array}$ & $\begin{array}{c}\text { Factor } \\
\text { Weigh } \\
\mathrm{t} \\
(\mathrm{y})\end{array}$ & $\begin{array}{c}\text { Actual } \\
\text { Weigh } \\
\mathrm{t} \\
(\mathrm{M})\end{array}$ \\
\hline 1 & \multicolumn{6}{|c|}{ Presence of Road Factor } \\
\hline & 0-50 & 663.45 & 0.026 & 100 & 0.518 & 51.86 \\
\hline & $50-100$ & 476.38 & 0.009 & 34.61 & 0.518 & 17.94 \\
\hline & $100-150$ & 332.57 & 0.005 & 19.23 & 0.518 & 9.97 \\
\hline & $150-200$ & 249.14 & 0.003 & 11.53 & 0.518 & 5.97 \\
\hline & $200-250$ & 179.36 & 0.000 & 0.000 & 0.518 & 0.000 \\
\hline & $250-300$ & 130.49 & 0.000 & 0.000 & 0.518 & 0.000 \\
\hline \multirow[t]{4}{*}{2} & \multicolumn{6}{|c|}{ Slope } \\
\hline & $<5$ & 297.25 & 0.010 & 47.619 & 0.242 & 11.542 \\
\hline & $5-30$ & $\begin{array}{c}1944.0 \\
0\end{array}$ & 0.021 & 100 & 0.242 & 24.24 \\
\hline & $>30$ & 33.00 & 0.000 & 0.000 & 0.242 & 0.000 \\
\hline 3 & \multicolumn{6}{|c|}{ Aspect } \\
\hline & $\mathrm{N}$ & 871.50 & 0.009 & 9.677 & 0.135 & 1.308 \\
\hline & $\mathrm{E}$ & 198.75 & 0.017 & 18.279 & 0.135 & 2.471 \\
\hline & $\mathrm{S}$ & 923.50 & 0.006 & 6.451 & 0.135 & 0.872 \\
\hline & $\mathbf{W}$ & 280.75 & 0.093 & 100 & 0.135 & 13.52 \\
\hline 4 & \multicolumn{6}{|c|}{ Presence of Rivers and Streams } \\
\hline & $0-50$ & 841.02 & 0.019 & 100 & 0.069 & 6.98 \\
\hline & $50-100$ & 634.59 & 0.013 & 68.42 & 0.069 & 4.77 \\
\hline & $100-150$ & 388.58 & 0.009 & 47.36 & 0.069 & 3.30 \\
\hline & $150-200$ & 218.30 & 0.003 & 15.78 & 0.069 & 1.10 \\
\hline & $200-250$ & 104.12 & 0.000 & 0.000 & 0.069 & 0.00 \\
\hline & $250-300$ & 45.31 & 0.000 & 0.000 & 0.069 & 0.00 \\
\hline 5 & \multicolumn{6}{|c|}{ Land Cover } \\
\hline & $\begin{array}{c}\text { Cultivatio } \\
\mathbf{n}\end{array}$ & $\begin{array}{c}1029.6 \\
6 \\
\end{array}$ & 0.022 & 100 & 0.031 & 3.18 \\
\hline & Forest & $\begin{array}{c}1087.8 \\
4\end{array}$ & 0.019 & 86.363 & 0.031 & 2.746 \\
\hline & Bush & 113.10 & 0.000 & 0.000 & 0.031 & 0.000 \\
\hline & Others & 36.19 & 0.000 & 0.000 & 0.031 & 0.000 \\
\hline
\end{tabular}

\section{Result and Discussion}

In this study, basically five factors were found to be actually responsible for the landslide occurrence. Generally we believe that as the degree in slope increases, the landslide density also increases but in this study there was no any landslide in the slope category of more than 30 degree and from this study, I found that the steep inclination does not necessarily means high occurrence of landslides. The study carried out by Ladas et al. (2007) [12], had also demonstrated the similar type of results. This may be due to having good vegetation cover, stable land and rocky outcrop in the study area. This is also due to the fact that slopes made of semi-consolidated and weathered rocks cannot be so steep. Such slopes are mainly developed in areas comprising of resistant massive carbonate rocks which are mainly subjected to rock fall hazard. In this study most of the landslide density was found in slope category of 5-30 degree which supports the findings of Maharjan, (2006) [15]. The similar result also supported by the findings of Shrestha et al. 2003 [22], that at higher slope gradient i.e. slope $>10 \%$ or 5.710 , the susceptibility of the land to mass movement increases.

While talking about the aspect factor, the western faces aspect had higher percentage of landslides which also supports the finding of Yalcin et al. (2007) [26]. Some of the meteorological events such as the direction of the rain, amount of sunshine, the morphologic structure of the area, the direction of the aspect towards a river and roads make 
the area susceptible to landslides. The hillsides receiving dense rainfall reach saturation faster, this is related to filtering capacity controlled by some parameters such as topographic slope, type of soil, permeability, porosity, humidity, the organic ingredients, land cover, and the season of the rain. As a result, pore water pressure on these hillsides increases and landslide also increases.

The distance from the road was also the important parameter of this study. Most of landslides were seen to proximity of the road. The high occurrence of landslides along the roads might be due to the effect of rainfall in softening the soil bed of unpaved roads, artificial excavation of lands at steep slopes for construction and maintenance of secondary roads and the passage of secondary roads through cultivated lands. The similar type of result was also shown in the study carried out by Akbar et al. (2011) [2]. Bagherzadeh Ali and Reza Mohammad (2012) [4], have clearly indicated in their study that the area closer to road area more susceptible to landslides where the activity of road construction substantially increased the instability of the land. Again Ayalew and Yamagishi (2005) [3] also have manifested the similar type of results and have taken the road construction as one of the important parameter or factor for landslide triggering. Moradi et al. (2012) [16] showed in their results that the distance closer to road is more susceptible to landslide. They indicated that roads change the nature of topography and decrease the shear strength of toe of slope and cause the tensile stress. Naturally, slope may be stable, but after road construction, road can have undesirable effect on slope. The road causes infiltrating of water in slopes and enforces extra stresses due to traffic loads. Similar to the effect of the distance to road, landslides may occur on the side of the slopes affected by river and stream. Rivers and streams at the study area may adversely affect stability by eroding the slopes or by saturating the lower part of the material until resulting in water level increases. Bagherzadeh Ali and Reza Mohammad (2012) [4] also have demonstrated that the area closer to the river and stream has high level of landslide susceptibility. Moradi et al. (2012) [16] indicated that the closeness of the slope to streams/rivers may adversely affect stability of slopes. River and stream increase the potential of landslide by erosion of the slope and increasing the degree of saturation of materials of slope. Dai F.C. and Lee C.F. (2002) [7] also have demonstrated that the landslides in river banks are often due to loss of land cover, steep slope topographic, and erosions. Yalcin et al. (2007) [26] again demonstrated the similar type of result in which they have indicated that most of the landslide density was observed within the class interval of $0-50 \mathrm{~m}$ and as the distance increases, the landslide density also significantly decreases. These all above mentioned findings supports my finding as well.

The effect of land cover on slope stability has been studied since 1960s. Generally, land cover has effect on strength of slope materials against sliding and control of water content of slope. In addition, plant roots reinforce the slope and normally are considered as reinforcements. Land cover absorbs the water of soil and decreases the potential of landslide. In studies performed by Komac (2006) [11] and Leventhal (2008) [14], this parameter has been considered as one of the most important factors in preparing landslide susceptibility maps. In this study, an increased landslide density is observed in cultivated land that is scattered between the patches of forest areas.

Although most of the landslides affect areas with broadleaved forest, the tree-less areas cause higher predispositions for landslides. According to other studies on the effects of vegetation on slope stability [5,18], it can be assumed that the strong and large root system of broadleaved forest helps to improve stability of slopes in the study area.

\subsection{Susceptibility Coefficient of the Study Area}

The susceptibility coefficient of the study area was calculated from the combination of all five factor maps employing the LHZ model and it was found to be ranging from 0-100. Thus the resulting LHZ map has the five classes of the susceptibility coefficient i.e. 0-27 as very low hazard class, 27-39 as low hazard class, 39-53 as medium hazard class, 53-74 as high hazard class and 74100 as very high hazard class. Table 7 shows the details of the LHZ map:

Table 7. Details of Landslide Hazard Zonation Map

\begin{tabular}{|c|c|c|c|c|}
\hline S.N. & Hazard Class & $\begin{array}{c}\text { Susceptibility } \\
\text { Coefficient }\end{array}$ & $\begin{array}{c}\text { Area in } \\
\mathrm{km}^{2}\end{array}$ & $\begin{array}{c}\text { Area } \\
\text { Occupied } \\
(\%)\end{array}$ \\
\hline 1 & Very Low & $0-27$ & 0.52 & 2.32 \\
\hline 2 & Low & $27-39$ & 4.61 & 20.35 \\
\hline 3 & Medium & $39-53$ & 11.93 & 52.24 \\
\hline 4 & High & $53-74$ & 3.38 & 14.28 \\
\hline 5 & Very High & $74-100$ & 2.49 & 10.81 \\
\hline
\end{tabular}

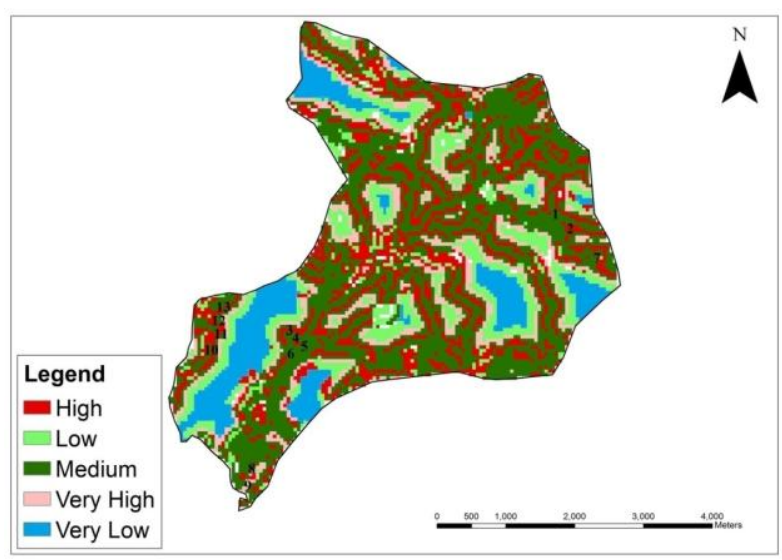

Figure 8. Landslide Hazard Zonation Map

From the hazard map (Figure 8), it was found that the majority of the area i.e. $52.24 \%$ falls on the medium hazard class while very small portion of the area i.e. $2.32 \%$ of the area falls on the very low hazard class. In order to prepare the landslide susceptibility maps, various methods such as fuzzy logic, statistic methods and AHP can be used for landslide susceptibility mapping. But in this study, AHP was entirely used for the preparation of landslide hazard zonation mapping. The AHP is a theory of measurement for dealing with quantifiable and intangible criteria that has been applied to numerous areas, such as decision theory and conflict resolution. The AHP method was used to define the factors that govern landslide occurrence more transparently and to derive their weights [27].The LHZ map so prepared demonstrates five hazard classes as very low, low, medium, high and very high. The majority of the area (almost 52\%) is in the 
medium hazard class. The similar type of result was also found in the study carried out by Yalcin et al. (2007) [26].

\subsection{Evaluation of the Applicability of the AHP and the LHZ Model in LHZ}

Finally, the Zonal Histogram Function in ArcGIS Spatial Analyst was used again to determine the percentages of area covered by landslide in different hazard classes in order to evaluate the applicability of AHP and LHZ model. From the output of analysis carried out using the Zonal Histogram Function, it was found that the percentages of area covered by the landslide increased with increase in the hazard probability i.e. the very low hazard class had the minimum landslide area percentage of even nil and the very high hazard class had the maximum landslide area percentage of $1.75 \%$ as shown in Figure 9. Therefore, the AHP and LHZ Model used in this study were considered to be applicable in LHZ of the study area.

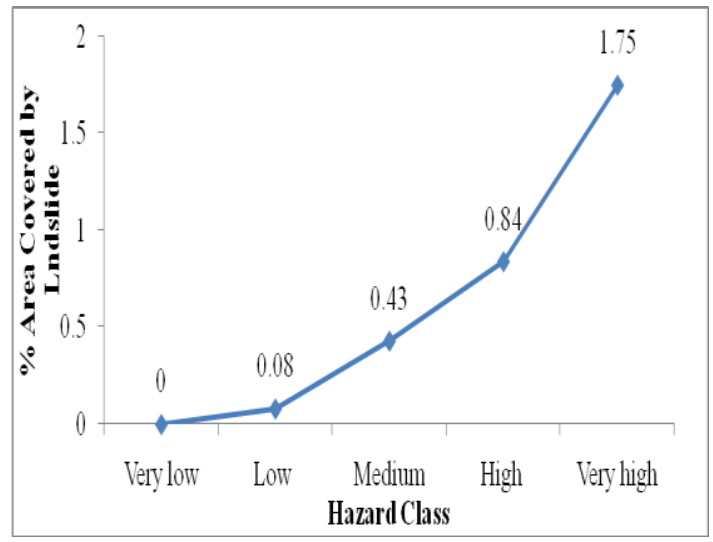

Figure 9. Percentage of Landslide Area Covered by Different Hazard Class

\section{Conclusion}

From the relational analysis, the study identified the responsible factors for the occurrence of the landslide in the study area were found as presence of road > slope > aspect > rivers/streams > land cover. From the final landslide hazard zonaton map, it can also be concluded that the majority of the study area lies under the Medium Hazard Class i.e. 52.24\% while only the minor portion of the area falls under Very High Hazard Class i.e. 2.32\%. Almost of the landslides were found within this slope range of 5-300. Also slope classes of $<50$ and more than 300 have very less amount of area in very high hazard class whereas the slope class of 5-300 has majority of the area in very high hazard class in comparison to other slope class. The study also revealed that the western aspect is more susceptible to landslide, which means that western aspect in the study area is more hazardous in comparison to other aspects. Cultivated land was found to be more susceptible to landslide in comparison to the other land cover. Road factor was found to be 7.50 times more hazardous compared river and stream factor.

Finally, it can be concluded that the Analytical Hierarchy Process used in this study is applicable for estimating the landslide hazard zonation of the study area.

\section{Acknowledgements}

I would like to express my profound gratitude and sincere thanks to my respected advisor Prof. Dr. Keshab Datt Awasthi for his constant supervision, guidance, suggestions, support and encouragement throughout my research period. My heartfelt acknowledgements go to my co-advisors Mr. Binod Prasad Heyojoo, Mr. Thakur Silwal and Mr. Gandhiv Kafle who have instantaneously supported me throughout the research work.

My special gratefulness and appreciation goes to the International Tropical Timber Organization (ITTO) and World Wide Fund (WWF) Nepal for providing me financial support to complete this work. I am also grateful to Department of Survey and Department of Mines and Geology for providing me the digital version of the map required for this study.

\section{Abbreviations}

$\begin{array}{lll}\text { AHP } & \text { Analytical Hierarchy Process } & \\ \text { DISCO } & \text { District Soil Conservation Office } & \text { Geographic Information System } \\ \text { GIS } & \text { Global Positioning System } & \\ \text { GPS } & \text { His Majesty Government, Nepal } & \\ \text { HMG/N } & \text { International Timber } & \text { Trade } \\ \text { ITTO } & \text { Organization } \\ & \text { Landslide Hazard Zonation } \\ \text { LHZ } & \text { Landslide } \\ \text { LS } & \text { Village Development Committee } \\ \text { VDC } & \text { World Wildlife Fund }\end{array}$

\section{References}

[1] Acharya G, De Smedt F, Long N.T, “Assessing Landslide Hazard in GIS: A Case Study from Rasuwa, Nepal," Bulletin of Engineering Geology and the Environment, 65(1). 99-107. March, 2006.

[2] Akbar Ali T and Ha Ryong S., "Landslide Hazard Zoning Along Himalayan Kaghan Valley of Pakistan-by Integration of GPS, GIS, and Remote Sensing Technology", Landslides, 8(4).527-540. December, 2011.

[3] Ayalew L., and Yamagishi H, "The application of GIS-based logistic regression for landslide susceptibility mapping in the Kakuda-Yahiko Mountains, Central Japan", Geomorphology 65(12),15-31. Feb, 2005

[4] Bagherzadeh A., \& Mansouri Daneshvar M. R., "Mapping of landslide hazard zonation using GIS at Golestan watershed, northeast of Iran", Arabian Journal of Geosciences, 5(20). May, 2012.

[5] Bathrellos G.D, Kalivas D.P, Skilodimou H.D., "GIS-based Landslide Susceptibility Mapping Models Applied to Natural and Urban Planning in Trikala, Central Greece, Estudios Geológicos, 65(1), 49-65.2009.

[6] Cevik E, Topal T., "GIS-based landslide susceptibility mapping for a problematic segment of the natural gas pipeline, Hendek (Turkey)", Environmental Geology, 44(8), 949-962. Nov, 2003.

[7] Dai F.C., and Lee C.F., "Landslide Characteristics and Slope Instability Modeling Using GIS, Lantau Island, Hong Kong", Geomorphology, 42(3-4), 213-228. Jan, 2002.

[8] Dai F.C, Lee C.F., Li J., Xu Z.W., "Assessment of landslide suspectibility on the natural terrain of Lantau Island, Hong Kong", Environmental Geology 40(3), 381-391. 2001.

[9] Esmali A., "Using GIS \& RS in Mass Movements Hazard Zonation -A Case Study in Germichay Watershed, Ardebil, Iran", Ph. D. Thesis, Tehran University, Karaj, Iran. 2003.

[10] Guzetti F., Carrarra A., Cardinali M., Reichenbach P., "Landslide hazard evaluation: a review of current techniques and their application in a multiscale study, Central Italy", Geomorphology, 31(1-4), 181-216. Dec, 1999. 
[11] Komac M., "A landslide susceptibility model using the Analytical Hierarchy Process method and multivariate statistics in perialpine Slovenia", Geomorphology, 74(1-4), 17-28. March, 2006.

[12] Ladas I., Fountoulis I., Mariolakos I., "Using GIS \& Multicriteria Decision Analysis in Landslide Susceptibility Mapping- a Case Study in Messinia Prefecture Area (Sw Peloponnesus, Greece)", Bulletin of the Geological Society of Greece, vol. XXXX, 13. May, 2007.

[13] Lan H.X., Zhou C.H., Wang L.J., Zhang H.Y., Li R.H.,"Landslide Hazard Spatial Analysis and Prediction Using GIS in the Xiaojiang Watershed, Yunnan, China", Engineering Geology, 76(1-2), 109-128. Dec, 2004

[14] Leventhal R.A., Kotze P.G., "Landslide susceptibility and hazard mapping in Australia for land-use planning with reference to challenges in metropolitan suburbia", Engineering Geology, 102(3-4), 238-250. Dec, 2008.

[15] Maharjan S.K., (2006) Investigation of Triggering Factors on Landslide Occurrence and Landslide Hazard Zonation -A GIS Based Approach, B.Sc.Thesis, Institute of Forestry, Tribhuvan University, 10-95, Feb, 2006.

[16] Moradi M., Bazyar M., Mohammadi Z., "GIS-Based Landslide Susceptibility Mapping by AHP Method, A Case Study, Dena City, Iran", Journal of Basic and Applied Scientific Research, 2(7), 9. 2012.

[17] Nagarajan R., Roy A., Vinod Kumar R., Mukherjee A., Khire M.V., "Landslide hazard suspectibility mapping based on terrain and climatic factors for tropical monsoon regions", Bulletin of Engineering Geology and the Environment, 58(4), 275-287. July, 2000.

[18] Neuhäuser B., Damm B., Terhorst B., "GIS-based Assessment of Landslide Susceptibility on the Base of the Weights-of-Evidence Model", Landslides, 9(4), 1-18. Nov, 2011.
[19] Paudel K.P., Mapping and Assessing Risk and Vulnerability of Water Induced Disasters in the Tinau Watershed, Western Nepal. Tinau Watershed Project. Kathmandu, 2004.

[20] Saaty T.L., The analytical hierarchy process, McGraw Hill, New York, 1980

[21] Sharma C.K., Geology of Nepal Himalaya and Adjacent Countries, Kathmandu, 16-30, 1990.

[22] Shrestha, D.P., Zinck J.A., Ranst E.V., "Modeling Land Degradation in the Nepalese Himalaya", CATENA, 57(2), 135156. Nov, 2003.

[23] Tianchi L., Landslide Hazard Mapping and Management in China. ICIMOD, Kathmandu, 1996.

[24] Turrini M.C., Visintainer P., "Proposal of a method to define areas of landslide hazard and application to an area of the Dolomites, Italy", Engineering Geology, 50 (3-4), 255-265. Oct, 1998.

[25] Yalcin A., "GIS-based landslide susceptibility mapping using analytical hierarchy process and bivariate statistics in Ardesen (Turkey): comparisons of results and confirmations", Catena 72(1), 1-12. Jan, 2008.

[26] Yalcin A., Bulut F., "Landslide Susceptibility Mapping Using GIS and Digital Photogrammetric Techniques: A Case Study from Ardesen (NE-Turkey)", Natural Hazards, 41(1), 201-226.April, 2007.

[27] Yao X., Tham L.G., Dai F.C., "Landslide Susceptibility Mapping Based on Support Vector Machine: A Case Study on Natural Slopes of Hong Kong, China", Geomorphology, 101(4), 572-582. Nov, 2008.

[28] Yohsimatsu H., Abe S., "A review of landslide hazards in Japan and assessment of their susceptibility using an analytical hierarchic process (AHP) method", Landslides 3,149-158. 2006. 